\title{
ОРЧИН УЕИЙН УРАН ЗОХИОЛЫН ХЭЛ, НАЙРУУЛГАД ХИЙСЭН ЗАРИМ АЖИГЛАЛТ
}

(Д.Батбаяр “Цахилж яваа гөрөөс” туужийн жишээгээр)

С.Мөнхсайхан

ШУА-ийн Хэл зохиольен хүрээлэн

\begin{abstract}
\end{abstract}
The author has studied the secret of a literature work which is the best representation of Modern Mongolian literature analyzing its style for the language education of the public.

Аливаа үндэстний хэл нь нийгмийн хөгжлийн эрт цагт зөвхөн хүмүүсийн хоорондын харилцааны хэрэглүүрийн үүрэг гүйцэтгэдэг байснаа улмаар нийгмийн хөгжлийн явцад түүний үүрэг улам бүр нэмэгдэн хэл нь харилцааны үүргээсээ гадна мэдээллийн ${ }^{1}$, хүний сэтгэлд нөлөөлөх ${ }^{2}$ хүнийг хүмүүжүүлэх зэрэг олон үүрэг гүйцэтгэх болжээ.

Эдгээр олон үүргээс хүний сэтгэлд нөлөөлж хүмүүжүүлэх үүргийг уран зохиол гүйцэтгэдэг бөгөөд ингэхдээ хэлний янз бүрийн хэрэглүүрийг ашигладаг байна. Уран зохиол нь нийгмийн ахуй, хүний амьдралын олон талт үзэгдлийг дүрслэн үзүүлдгээрээ сэвдийн хувьд маш өргөн хүрээтэй, үүнээс хамааран хэлний материал буюу хэлний арга хэрэглүүрийг сонгон авах бололцооны хувьд ч бусад найруулгаас харьцангуй чөлөөтэй байдаг. Уран зохиолын найруулгын бусад найруулгаас ялгарах гол онцлог нь үгийн дүрслэн илэрхийлэх, хүний сэтгэл хөдөлгөх шинжийг хамгийн ихээр нээж, үгийн хийсвэрлэсэн, шилжсэн, егөөдсөн, ёгтолсон, утга бууруулсан, ихэсгэсэн зэрэг утгыг ашиглах боломж хамгийн их байдаг [3:4]. Иймээс ч зохиол бүтээлийн хэл найруулгаас шалтгаалдаг зохиолын чанар, зохиолын хүний сэтгэлд нөлөөлөх чадал нь зохиолч тухайн хэлний дээр дурдсан эрдэм чадлыг хэр зэрэг эзэмшсэн түүнээ хэрхэн ашиглаж чадаж байгаагаас ихээхэн шалтгаалдаг байна. Бид зохиолчийн энэхүү эрдэм чадал нь тухайн зохиол бүтээлийн чанар чансаанд хэрхэн нөлөөлж байгааг соёлын гавьяат зүтгэлтэн Д.Батбаярын “Цахилж яваа гөрөөс" туужаар төлөөлүүлэн уг туужийн шилдэг болж чадсан нууцыг нээхээр туужийн зохиолын хэл найруулгад багахан судалгаа хийснээ танилцуулж байна. “Цахилж яваа гөрөөс” туужид монгол жирийн хүн тэр дундаа малчин хүний зан ааш, бодол санаа, аж амьдрал, түүнд учирч буй элдэв саад бэрхшээл, хүмүүсийн хоорондын харилцаа зэргийг хөндсөн манай монголын орчин үеийн уран зохиолын шилдэг төлөөлөл болж чадахуйц бүтээл юм. Аливаа улс түмний шилдэг бүтээл хэний ч болов сэтгэлийн гүнд шингэж, хүний сэтгэлийн утсыг хөндөн хязгааргүй баярлуулахыг зэрэгцээ чөлөөт сэтгэлгээ, хэлний яруу мэдрэмж, гярхай егөө, гялалзсан хурц ухаан, халуун дотно аяс, эрхэм ёс болон үзэн ядах сэтгэл гэх зэргээр ер хүний бодол сэтгэлийн олон өнгийг ялгаруулан болон холилдуулан гаргадаг [6:260] бөгөөд зохиолч энэ бүгдийг хэрхэн мэдэрч, ашиглаж чадаж байна вэ гэдгээр тухайн зохиолын үнэ цэнэ хэмжигддэг бизээ.

“Цахилж яваа гөрөөс” туужийн гол үйл явдал нь Дамба, Дэжид хэмээх хосын амьдралын нэгэн эгзэгтэй агшны тухай өгүүлнэ. Дамба Дэжид хоёр бол жирийн нэгэн малчин гэр бүл бөгөөд бусад хүмүүсийн нэгэн адил өөрсдийн амьдралаа зохион арван хэдэн жил хамт

\footnotetext{
1 Энэ үүргээ хэл нь ярианы болон бичгийн аль нэг хэлбэрээр леки яриа, сонин хэвлэл, ном зохиол, радио телевизийн нэвтрүүлэг зэрэг соёл шинжлэх ухааны бүхий л салбарт гүйцэтгэнэ. Ш.Гаадамба, 1989, х.99

2 Хэл энэ ҮҮргээ уран зохиолоор дамжуулан хэрэгжүҮлнэ. Ш.Гаадамба, 1989, х.99
} 
амьдарсан хүмүүс юм. Энэ хугацаанд тэд эрвийх дэрвийхээр зүтгэсээр нутагтаа гайгүй сайн малчин гэж гэгдэж мөн амьдралын баяр баясал (хурим найр хийж гэр бүл болсон, үр хүүхэд гарсан гэх мэт), гуниг зовлон (ойр дотны хүмүүсээ алдах гэх мэт)-г бусдын адил амсаж, эдэлж явсаар зохиолын гол зангилаа болсон тэрхүү эгзэгтэй агшинд ирнэ. Гэрийн эзэн Дамба нутгийн халзан Дэлэг хэмээх хүний охин Тогоохүүд бага багаар татагдсаар нэг л мэдэхэд түүнээс холдож чадахаа байж өөрийн авааль эхнэр Дэжидтэй буцаж нийлэх үҮ, эсвэл Тогоохүүтэй хамт амьдрах уу гэсэн сонголтын өмнө ирнэ. Харин эхнэр Дэжид энэ явдлыг хүлээн зөвшөөрч чадахгүй байгаа хэдий ч эр нөхрөө салаад өөр хүнтэй суугаад явахыг нь ч бас хүссэнгүй. Гэвч энэ хэрэг явдал Дамба Дэжид хоёрын хэн хэнийх нь бодож санаж байснаар шийдэгдсэнгүй, Дэжид Дамбаас гэдсэндээ хүүхэдтэй салж, Дамба Тогоохүүтэй амьдрахаар болно. Зохиолын үйл явдал зөвхөн Дамба Дэжид хоёрын салалтын тухай өгүүлж буй мэт боловч Дамба Дэжид хоёрын тус тусын бодол санаа, амьдралыг үзэх үзлээр дамжуулан зохиолч нэгэн гэр бүлийн арван хэдэн жилийн амьдрал, цаашилбал хүний нэгэн насны амьдралын утга учрыг өгүүлэхийг эрмэлзсэн мэт санагдана. Туужийн үйл явдал зохиолын гол баатар болох Дэжид өөрийн эр нөхөр Дамбыг өөр хүнтэй болоод гэртээ ирэхээ больсныг мэдэх үед гэрийн эзэн Дамба гэртээ ирж буйгаар өрнөнө. Тэд энэ удаад учраа ололцсонгүй, түүний дараа ч хэл амаа ололцож чадахгүй хэн хэнийхээ хэлсэн үгэнд эмзэглэн чухам яагаад ийм хэрэг явдал гарах болсон хийгээд яагаад энэ гэр бүл салах болов, тэд аз жаргалтай, утга учиртай амьдарч байсан эсэх цаашилбал хүний амьдралын утга учир юунд байдаг, аз жаргал гэж юу болох зэргийг тус тусдаа тунгаан бодно. Эдгээр бодол эргэцүүллийн явцад зохиолын баатруудын зан төрх, тэдний харьцаа илрэх бөгөөд тэдний хэлсэн үг яриа, хийж байгаа үйлдэл бүхнээр зохиолчийн гаргах гэсэн санаа илрэх ажээ.

Туужийн уншигчдын сэтгэлд хүрсэн шалтгаан нь нэгдугээрm, зохиолчийн дүрслэн бичих чадвар юм. Зохиолч баатруудын хооронд үүсч буй үг яриаг зүгээр нэг энгийн үгээр бичсэнгүй, түүнийг тухайн агшин, тухайн нөхцөл байдал дунд үүсч болох уг хүний сэтгэлийн хөдөлгөөн, зан араншин, үйл хөдлөлтэй нь хамт дүрслэн үзүүлснээрээ илүү амьдлаг, уншигчдад жинхэнэ болж буй хэрэг явдал мэт сэтгэгдлийг төрүүлж байна. Энэ нь зохиолын үйл явдалд зохиолчийн хэлэх гэсэн санаа агуулагдахаас гадна бас уншигч өөрөө зохиолын үйл явдлаас ургуулан өөрийн дүгнэлтээ хийх боломжийг олгож байгаа юм. Иймээс ч уг зохиолын хэл найруулга энгийн юм шиг атлаа хүний сэтгэлд хүрч чадахуйц сайн болж чаджээ. Жишээ нь, Дэжидийн ах Дамбынд ирээд (Дамбыг “Халзан Дэлэгийнд хэвтэж байна" гэж хүмүүсийн яриаг сонсоод) Дэжидээс “Дамба хаачаав" гэж асуухад Дэжидийн “Сум орсон гэсэн” хариултад эгдүүцэн загнасан нь

- “Яасан арилсан дотортой амьтан бэ? чи. Чиний наад хоёр нүд чинь юү Үзэж, хоёр чих чинь юү сонсож байдаг юм. Хүнд чинь нэр нүҮр гэж байдаг. Та нар чинь яачихсан иагаандаа гарчихсан улс вэ. Үгүй ядахдаа амьтан ах дҮүгээс ичдэг байгаа даа. Хн! "Сум орсон гэнэ шүҮ” Сум орсон хүн халзан Дэлэгийнд хэвтэж байдаг юм уу. Яахаараа ... чи ч чи! Яагаад эр нөхөр шүҮ юмаа татаж авдаггүй юм" гэснээ хариу хүлээх мэт дуугүй болов (х.17) хэмээн дүүгээ загнаж байна. Уг нь Дэжид энэ тухай мэдэж байсан бөгөөд Дамбыг сайн мэдэхийн хувьд ийм юм болсон байх учиргүй, Дамба түүний мэдэх хамгийн сайн хүн учир өөр хүнтэй болсон байх ёсгүй, тиймээс ч ийм хэрэг болсон гэдэгт итгээгүй, итгэхийг ч хүсээгүй, түүний тухай хүмүүсийн ярьсан үнэн худал нь мэдэгдэхгүй яриаг өөрийн бодлоороо зөвтгөж буруу өгч чадахгүй явсан. Харин энэ үнэн худал нь мэдэгдэхгүй (худлаа байгаасай гэж чин сэтгэлээсэээ хүсч байсан) мэдээг хэн нэгэн явуулын хүн биш, бүр эсрэгээр түүний төрсөн ах (магадгүй энэ явдлыг битгий сонсоосой гэж бодож явсан ганц хүн нь) ирж хэлсэн нь түүнд хариу хэлэх ямар ч шаардлага байсангүй, ахын энэ асуултын 
хариу нь “хариу үл өгөх” (энэ нь угтаа би бүгдийг мэднэ гэсэн хариулт) бөгөөд энэ үед түүний дотоод сэтгэлд үүсч буй хямралыг зохиолч ийнхүҮ өгүүлжээ.

“Дэжнд энэ тухай хэлэх вий гэхээс айн, яс хавталзан суусан бөгөөд эдгээр угсийг сонссоноос хойш яагаад ч юм мөнөөх айдас нь огт алга болж, одоо юу ч хэлсэн, юу ч ярьсан түҮнд ялгаагуй мэт санагджээ" (х.17) гэсэн нь хоёр хүний хооронд болж буй жирийн нэг яриа бус, тэдгээр хэлсэн болон “хэлээгүй үг” бүрийн цаана тухайн хоёр хүний дотоод сэтгэлийн хямрал зөрчил, хүн хүнээ хайрлах “хайр нь дотроо хал нь гаднаа" хайр, мөн хүн хүнээ түүн дотроо ахмад хүнийг хүндэтгэх, ахмад хүний үгийг сонсож сурсан монгол хүний хүмүүжил зэрэг зохиолчийн зохиолын үйл явдлаар өгүүлэх гэсэн олон зүйл нуугдаж байгааг олж харж болох юм. Үүний дараа Дэжидийн ахын хариу хүлээж суухдаа гаргаж буй зан байдлыг өгүүлэхдээ “Ах нь архинаасаа дахин аягалж нүдээ тас анин залгилж дуусгаад ярвайн амаа арчсанаа дотор нь сая онгойсон янзтай санаа алдаад Дэжид рүУ зэрвэсхэн харснаа өрөвдсөн ч юмуу, аль эсвэл уурласан дүр Үзүүлэх гэснээ удаан тэгж чадахгүйгээ мэдсэн ч юм уу дуугаа зөөлрүҮлэн ...” (х.17) гэж бичжээ. Үүний ах нь “архинаасаа дахин аягалж" гэдэг нь ах нь архи уух дуртайдаа бус Дэжидийн хариуг хүлээн цаг хороож буйг, "нүдээ тас анин залгилж дуусгаад ярвайн амаа арчсанаа" гэдэг нь архины гашуунд, эсвэл архины гашуунд бус Дамбын явдалд дургүй нь хүрсэн эсвэл Дамба Дэжид хоёрын байгаа энэ байдал (нэг нь өөр айлд очоод “хэвтчихсэн”, нөгөө нь түүнийг нь мэдсэн ч юм шиг, мэдээгүй ч юм шиг юу ч хэлэхгүй байгаа, түүнчлэн энэ айлын эхнэр нөхөр хоёрын энэ арчаагүй байдал зэрэг нь) ахынх нь дургүйг хүргэсэн байж болох ба үүнийг зөвхөн уншигчид өөрсдийн үзэл бодол, амьдралын туршлагаараа шүүн тунгаах бөгөөд Дэжид эрхбиш түүний төрсөн дүү (мөн түүний түшиж тулах эр нөхөр нь дүүг нь хуураад яваа) учир эрхгүй дүүгээ өрөвдөж байгааг зохиолч маш энгийн хэл үгээр гэхдээ уншигчдын дотоод сэтгэлийг хөндөж чадахуйц хэмжээнд дүрслэн үзүүлсэн байна.

Хоёрдугаaрm, зохиолчийн найруулан бичих ур чадвар буюу үг сонголт нөлөөлжээ. Уран зохиолын хэл найруулгад нөлөөлдөг гол зүйл бол үг сонголт юм. Найруулгын өнгө аяс оновчтой хэрэглэсэн ганц л үгэнд тодордог. Мөн үүний адил буруу сонгосон нэг л үг найруулгад нөлөөлж уран зохиолын хүний сэтгэлд нөлөөлөх хүчийг бууруулдаг ажээ. Зохиолын үйл явдал, санаа бодлыг илтгэсэн үг нь яг үнэн бодитойгоор онож хэлсэн, өөр ямар ч үгээр солихын аргагүй байж чадвал найруулга сайн болдог [6:77]. Ийм жишээ “Цахилж яваа гөрөөс" туужид олон тааралддаг. Тухайлбал,

“Тэгтэл нэг өдөр олж ирэх ёстой хүрэн үрээ нь өөрөө ижилдээ иржээ. Энэ явдал Дэжидийн голыг гонсойлгож амьтны хэл амаа билүүдээд байгаа нь ортой байх нь гэсэн сэжиг сэтгэлд нь орогнон, түүнийг бодох санах, идэх уухийг нь хүртэл мэддэг болов. Яг энэ Үед ах нь иржээ” (х.15) гэсэн зохиолын энэ хэсэгт “... гэсэн сэжиг сэтгэлд нь орогнох” гэсэн хэллэгт ажиглалт хийе. “Сэжиг сэтгэлд нь орогнох” гэдэг нь “уг зүйлийн талаар үнэн худлыг нь гүйцэд мэдээгүй учир тэр сэжиг түр зуур л төрсөн, худал гэж мэдвэл амархан арилна" гэсэн утга илтгэхийн зэрэгцээ тухайн зохиолын баатрын зан байдал (Дэжид нөхөртөө маш их итгэдэг)-ыг давхар тодруулж байна. Хэрэв үүнийг “сэжиг сэтгэлд нь төрөх" юмуу “сэжиг сэтгэлд нь буух" гэх зэргээр бичсэн бол дээрх санаа гарахгүй байх байсан. Өөрөөр хэлбэл, Дэжидэд тухайн “сэжиг төрсөн” бол Дэжид эр нөхөртөө итгэдэггүй, эсвэл Дамба үргэлж тиймэрхүү зүйл хийж явдаг гэсэн утгатай болно. Харин “сэжсиг орогносон” учир Дэжид тухайн зүйлд үнэмшиж чадахгүй байсан, учир нь тэрээр эр нөхөртөө итгэдэг, эр нөхрөө тийм юм хийж явна гэдэгт итгэж чадахгүй байгаа зохиолын баатрын зан байдалд тохирсон хэллэг болжээ гэж хэлж болно.

Түүнчлэн зохиолд “(Дамбын гэрт Дэжидийн ах ирээд) Ямар хэргээр яваа нь бүY мэд, байдльг нь ажихад нэг л янзгүй мал бүрэн эсэхийг асууж лавласныхаа дараа дуртай дургүй 
“Дамба хайчаав?” хэмээн асуужээ. Энэ асуулт ияаанаа нэг юм хадгалаад ч байгаа юм шиг, Дамбыг хаа явааг чи мэдэх ҮY ч гэсэн юм шиг сонсогдоход ...” (х.16) гэсэн Дэжидийн ахтайгаа ярьж буй хэсэгт “хадгалах" гэдэг үгийг тун оновчтой хэрэглэжээ. Энэ үгийн оновчтой болсон учрыг өөр үгээр орлуулан хэлж үзэхэд л мэдэгдэнэ. Жишээ нь, “энэ асуулт цаанаа нэг юм нуугаад ч байгаа юм шиг”, “энэ асуулт цаанаа нэг юм хэлээд ч байгаа юм шиг” гэх юмуу эсвэл “энэ асуулт цаанаа нэг юм агуулаад ч байгаа юм шиг” гэх зэргээр соливол Дэжидийн ах түүний байдлыг мэдэх гэж туршиж хэлсэн үгийн өнгө аяс гарахгүй байна. Чухам “энэ асуулт цаанаа нэг юм хадгалаад ч байгаа юм шиг” гэж хэлснээр 1. Дэжидийн ах Дэжид Дамба хоёрын явдлыг мэдээд энэ талаар дүү нь ямар бодол санаатай явааг мэдэхээр туршиж асуусан; 2. Дэжид ахынхаа хэлсэн энэхүү үгийн байдлаас ах нь ямар нэг юм гадарлаад түүнийг туршиж байна (чи ер нь эр нөхрийнхөө хаагуур юу хийж явааг мэдэж байна уу, ингэхэд та хоёр юу болоод байна) гэсэн бодлыг уншигчдад төрүүлж байгаа юм. Үүнээс үзэхэд үг оновчтой сонгоно гэдэг бол заавал мэргэн цэцэн, уран гоё үгээр хөөцөлдөхийн нэр биш, харин тухайн үгийн утгыг сайтар ухаж мэдсэний үндсэн дээр оновчтой газар нь хэрэглэх өөрөөр хэлбэл, зохиолчийн гаргах гэсэн санаа үгийн утга хоёр давхцаж байхыг хэлдэг байна.

Зохиолын хэл найруулгад дан үг (түүнээс үүсэх нийлэмж үг)-ээс гадна хэвшмэл хэллэг онцгой үүрэгтэй. Ончийг нь олсон хэвшмэл хэллэг зохиолын дүр дүрслэлийг улам яруу болгохын зэрэгцээ тухайн зохиолын баатрын зан байдлыг тодруулах, зохиолын үйл явдлын хүний сэтгэлд нөлөөлөх хүчийг ихэсгэх зэрэг олон талын ач тустай. Тухайлбал, “Цахилж яваа гөрөөс" туужид олон тооны өвөрмөц хэллэг гарч байгаагаас дурдвал, “Зуны дэлгэр ияагт хааяа хэд гурав хоногоор айраг архи, найр иээнгл хөөж яваад ирэхэд нь угтан гүйж ирэх ХүҮдээ баярлан, хүүгээрээ ул барин гэртээ орж нүҮр хагардаг байсан нь нэг бус билээ" гэсэн хэсэгт зохиолч “хүүгийнхээ баярласан сэтгэлээр далимдуулан эхнэрийнхээ сэтгэлийг засан гэмээ цагаатгадаг” байсныг “ул барих” гэсэн хэллэгээр гаргажээ. Мөн “Дэжид Дамбын тухай сонссон дуулснаа эргэн бодож, бодох бүрийдээ Үүнийг хэлсэн хүн хэн билээ. Үнэн Үг хэлэх хүн билүУ, үгүй билүY хэмээн эргэиүүлж, нуруутай хүн сэн гэж бодохтойгоо зэрэг гол нь харлан олхиогүй худалч, хоосон ховсоргон хүний амнаас дуулсан ч болоосой хэмээн харуусахдаа Дамбад бус мөнөөх муу ёрын үг тээж⿻ авчирсан хүнд уур нь хүрч, тийм Yг хэлснийх нь төлөө мэндлэхэд нь дуугарахгүй болчих юмсан гэж нэг бодож ...” (х.10) хэмээн Дэжид Дамбын тухай бодож буй хэсэгт гарч байна. Энэ хэсэгт хоёр хэвшмэл хэллэг орсны нэг нь “нуруутай хүн” юм. Монголчууд “төлөв томоотой, хүний итгэл даадаг, хүнд түшиг болохуйи, илүү дутуу үг ярьж хүний хооронд хов хутгадаггүй, хэлсэн үг нь жинтэй байдаг" гэх мэт олон чанарыг өөртөө агуулсан хүнийг “нуруутай хүн” гэдэг. Зохиолч Дэжидийн ахыг тодорхойлохдоо дээр дурдсан олон зан чанарыг бүгдийг тоочин хэлсэнгүй ганцхан “нуруутай хүн” гэж тодорхойлсноороо уншигчдад Дэжидийн ах бол “худлаа хэлэх хүн биш” гэсэн ойлголтыг товч өгч байгаагийн зэрэгцээ найруулгад тавигддаг “товч бөгөөд тодорхой байх" гэсэн зарчимд нийцсэн байна. Үүний дараа “муу ёрын үгийг тээж авчирсан хүн” гэсэн хэсэгт зохиолч “үг тээж авчрах” гэдэг хэлцийг ашиглажээ. Энэ нь “тухайн үгийг санан санан явсаар зориуд ирж хэлсэн” утга гаргах ба үүнийг "муу ёрын үг дуулгасан", “муу ёрын үг хэлсэн”, “муу ёрын үг зөөсөн” гэх мэтээр хэлбэл өмнө өгүүлсэн “тухайн үгийг санан санан явсаар зориуд ирж хэлсэн” гэсэн утга ер гарахгүй байсан бөгөөд тухайн үгийг хэрэглэснээр зохиолч үгээ зөв сонгосон төдийгүй, тухайн хэлцээр а. Тухайн хэрэг явдлыг санан санан явсан; б. Зориуд ирж хэлсэн гэсэн хоёр санааг ганцхан уг хэлцээр илэрхийлж найруулгын товч тодорхой байх зарчмыг хангажээ. Үүнтэй адил жишээ зохиолд олон гарч байгааг товч танилцуулбал,

aм харах - 1. Хүнийг аяыг харах, хэлснээр нь хийх: “Хаа нэг ам мурайхдаа ч салах 
сарних үгийг хэлэх нь бүY хэл, өөдөөс нь хараал ч хэлж яваагүй, эзгүй хойгуур нь хонь малаа бүрэн бүтэн адуулаад болоод байдаг хэрнээ юүхэн дээр ч ингэх ҮY тэгэх ҮY хэмээн ямагт түҮний амыг харэ⿻, түҮнээс өөр эр хүн орчлон дээр үгүй юм шиг явдаг Дэжид ийм үг хэлнэ гэж хэн санах вэ” (х.9); 2. Зөвшөөрөл хүсэх - “Уг нь ав ав, эр хүнд сайн мориноос илүүюм хэрэг байдаггуй л юм гэх нь билээ гэчихэд л авчихна л даа. Ухаандаа миний амыг л харжс байгаа хэрэг" (х.15).

ам данс тусгаарлах - Нас биед хүрч эхнэр авч (нөхөрт гарч) өөрийн амьдралыг зохиох: “эиээг нь хар нялхад нь нас барж, эгч ах нар нь айл гэр болж ам данс тусгаарласан болохоор гэр мальнн ажилд гани бие хүрэлиэхгүй байна гэдэг нэрийдлээр эх нь Дэжидийг долдугаар ангид орох намар сургуулиас нь гаргасанд ...” (х.11)

хэл амаа билүүдэх - Хов ярих, тухайн зүйлийн талаар үнэн худлыг нь мэдэхгүй байж ам ам дамжуулан шуугин ярих: “Энэ явдал Дэжидийн голыг гонсойлгож амьтны хэл амаa билүудээд байгаа нь ортой байх нь гэсэн сэжиг сэтгэлд нь орогнон, түүний бодох санах, идэх уухийг нь хүртэл мэддэг болов" (х.11)

тэнгийн булан даахгүй - Нас балчир, хүч чадал суугаагүй: “Үхсэн хойноо зөөх! Тэнгийн булан даахгүй хуруун чинээ нялх хүүхэд та хоёр яаж зөөх юм” (х.17)

цагаандаа гарах - Ичиж зовохоо болих: “ХҮнд чинь нэр нүҮр гэж байдаг. Та нар чинь яачихсан цагаандаа гарчихсан улс вэ. Үгүй ядахдаа амьтан ах дүҮгээс ичдэг байгаа даа" (x.17)

яс хавталзах - Ичиж зовон айж эмээх: “Дэжсид энэ тухай хэлэх вии гэхээс айн, яс хавталзан суусан бөгөөд эдгээр угсийг сонссоноосоо хойш яагаад ч юм мөнөөх айдас нь огт алга болж, одоо юу ч хэлсэн, юу ч ярьсан түүнд ялгаагуй мэт санагджээ” (х.17)

ам муруйх - Маргалдах: “Гээд эр хүн хойно учраа олчихноо. Харин чи л ам муруйх болгондоо урьд хойчийн юм сөхөөд байв даа. Тэгвэл ч сайнаа үзэхгүй шүү” (х.18)

хор маажих - Тэчьядам үг хэлж хүний эгдүүг хүргэх: “Дэжид ийм уужуу тайван, ийм битүүхэн түншсэн үг хэлчихсэнээ өөрөө ч мэдрэн, Дамбын хорыг маажнжс чадсандаа эрэмшин улам ч тайван хэнэггуй изарайлан ...” (х.19)

үнсэнд хаягдсан шалз шиг - Хэрэггүй болон хаягдах: Гай гэж байдаг юм бол тэр нь дайрч л байг. Тэртэй тэргүй хэнд ч хэрэггүй үнсэнд хаясан шалз шиг амьтан үхсэн ч яадаг юм. Хэнд хэрэгтэй гэж амьд явах юм. (х.23)

нэг нэр хоёр хоч - Элдэв хэрэгт орооцолдон муу нэртэй болох: “ЭнэхүY уур гомдол нь хаа нэгтээ сэтгэлийн мухарт доромжлогдсон, басамэлагдсан гэдэг санааг бүдэг бадаг төрүүлэх бөгөөд тийм санаагаа бүҮр түүрхэн мэдрэх бүр “нэг нэг хоёр хоч. Ер хэлүүлэв YY, ТогоохҮҮг аваад хаамаа ч юм явчихалтай нь билээ” хэмээн бодсоноо...” (х.27)

гар мухар - Гар хоосон, юу ч үгүй: “Дархныхаа хэрэгслийг авдаг байж, чөдөр ногт зангидахаас эхлээд хийх юм хаа мундах вэ. Юуюуч үгүй гар мухар гарснаа санах авч тэрхэн уед дархны хайриаг бүҮ хэл тамхиныхаа хүҮдийд тамхи дүүргээд авчих сэхээ байгаагүйгээ санан гунихрав" (х.27).

Зохиолд энэ мэтчилэн үг оновчтой сонгосон жишээ олон байхын зэрэгцээ зарим нэг засууштай үг хэллэг тохиолдож байна. Тухайлбал, Дэжидийн ах Дамбын гэрт ирээд Дэжидийг

“Үхсэн хойноо зөөх! Тэнгийн булан даахгүй хуруун чинээ нялх хүүхэд та хоёр яаж зөөх юм. Яасан арилсан дотортой амьтан бэ? Чи. Чиний наад хоёр нүд чинь юу Үзэж, хоёр чих чинь юу сонсож байдаг юм" (х.16-17) гэж загнаж буй хэсэгт “Яасан арилсан дотортой амьтан бэ? чи” гэдгийг “Яасан амгалан дотортой амьтан бэ? чи” гэж соливол илүү оновчтой болох мэт санагдаж байна. Учир нь, “арилсан дотортой амьтан” гэдэг нь монгол хэлэнд “хүний үнэргүй, хүн чанаргүй, хүний мөсгүй” зантай хүнийг хэлэх бөгөөд зохиолын үйл 
явдлаас үзвэл Дэжид тийм хүн чанаргүй хүн бус харин эр нөхөр нь гэртээ олон хоног ирэхгүй байгаа, хүн амьтны амнаас өөр айлд байна гэдгийг нь дуулсан атлаа үнэн худлыг нь мэдэхийг хичээхгүй гэртээ ирэхийг нь хүлээн сууж буй зэргээс үзэхэд “амгалан дотортой хүн” нь илүү тохирч байна. Түүнчлэн зохиолын 35-р талд

“... Дамбыг аль болохоор ая тааваар нь байлгахыг хичээн ийм тийм ажил ундрах бүр “Аав яв, ээж хий” гээд юуг ч түҮнд эс хавьтуулах бөгөөд голиуу л хоёулхнаа байх арга замыг эрэлхийлэн тийм замыг олмогцоо юу ярих, яах ийхээ өөрөө ч мэдэхгүй, хий л Дамбын аяс харан түүний изарайчлах нь улам ч сэтгэлийг нь хөндүүрлүүлнэ" гэсэн хэсэгт “хоёулхнаа байх арга замыг эрэлхийлэх" гэдгийг “хоёулхнаа байх арга саамыг эрэлхийлэх" гэвэл илүү тохиромжтой юм. Учир нь “арга зам" гэвэл “аливаа үйлийг бүтээх боломж, ур ухаан, эв дүй” [2:129] гэсэн утгатай, “арга саам” гэвэл “а. Үйл явдал, ажил хэргийг удаашруулах, алдагдуулах, өөрийн санаснаар эргүүлэх элдэв шалтаг, цаг нөхцөөх байдал; б. Ажил хэргийг хийж гүйцэтгэх боломж сүйхээ” [2:129] гэсэн хоёр өөр утгатай хоршоо үг юм. Мөн зохиолын 38-р талд

“- За би мэдэж байна. Харин ингэсхийж байгаад нүҮж буугаад чи бид хоёр илҮҮ гэрээ барих нь өлзий болох байх мүү.

- Юу?! Чи чинь галзуурав уу?

- За за дуугаа аяд. ХҮҮхэд шуухад сонсчихвол хар яршиг гэх сонсогджээ” гэсэн Тогоохүүгийн эцэг эх хоёрын ярианы хэсэгт “Хүүхэд шуухад” гэсэн хоршоо үгийг “хүүхдүүд” гэвэл илүү оновчтой болно. “Хүүхэд шуухад” гэдэг нь ихэвчлэн бага насны хүүхдийг хэлдэг учир “хүүхдүүд” гэвэл “Дамба Тогоохүү хоёр” гэсэн санаа гарах юм.

$$
* * *
$$

Уран зохиолын хэл найруулгад дээр дурдсан зүйлүүдээс гадна үгийн олон утга багагүй нөлөөтэй, өөрөөр хэлбэл, үгийн олон утгыг хэдийчинээ оновчтой ашиглана найруулга төдий чинээ ойлгомжтой болж чаддаг [3:15] байна. Найруулга зүйд ойролцоо, эсрэг гэдэг нэр нь харьцангуй өргөн утгатай бөгөөд бид энэ удаад тэдгээрийн үгийн сангийн талаас найруулгад гүйцэтгэж буй үүргийг нь ажиглан үзлээ.

Ойролцоо үг. Хэлэнд ойролцоо утгатай үг байна гэдэг бол юм үзэгдлийг олон талаас нь илүү нарийн дүрслэн илэрхийлэх боломж олдож байна гэсэн үг юм. Өөрөөр хэлбэл, хэлний тусламжтайгаар адил төсөөтэй юм үзэгдлийн үл мэдэгдэх жижиг ялгамжаат чанарыг ч гэсэн хэлэнд нарийн тусгахын үүднээс ойролцоо утгатай үгийг хэрэглэдэг байна [7:36]. “Цахилж яваа гөрөөс" туужид ч гэсэн ойролцоо үгийг ашигласан жишээ маш арвин байна. Жишээ нь, Дамбын эрэл сурал, аймаг сум орохоор хэд гурав хоногоор эзгүй яваад, ирэх барааг нь харангуут царай зус нь гэрэлтэн нүүр рҮүгээ унжсан Үсээ хойш илю, үргэлж толгой дээрээ явах, нар салхинд онгож хээ нь мэдэгдэхээ больсон алчуураа засч яаран сандран гэртээ орж юм хумаа иэгцэлдэг байснаа чухам хэдийнээс больчихсоныг өөрөө ч үл мэднэ (х.5) гэсэн зохиолын хэсэгт эрэл сурал, аймаг сум, хэд гурав, царай зүс, яаран сандран, юм хум гэсэн ойролцоо үгийг хоршин хэрэглэжээ. Монгол хэлний ойролцоо үгийн нэг онцлог бол өөр хоорондоо хоршин хэрэглэгдэж найруулгад чухал үүрэг гүйцэтгэдэг [4:130] ба, ингэхдээ тэдгээрийн хэр олон, цөөн нь бус хэр оновчтой хэрэглэсэн нь найруулгад нөлөөлдөг бөгөөд түүнийг өөр үгээр солиход л мэдэгдэнэ. Тухайлбал дээр дурдсан өгүүлбэрийг,

Дамбын эрэл хийх, аймаг орох, сум орохоор хэд хоногоор эзгүй яваад, ирэх барааг нь харангуут иарай нь гэрэлтэн нүҮр рүүгээ унжсан Үсээ хойш илж, үргэлж толгой дээрээ явах, нар салхинд онгож хээ нь мэдэгдэхээ больсон алчуураа засч яаран гэртээ орж юмаа иэгиэлдэг байснаа чухам хэдийнээс больчихсоныг өөрөө ч үл мэднэ (х.5) гэж засвал энэ нь 
утгын хувьд хүнд ойлгогдох боловч уран зохиолын найруулгын гол шаардлага болсон уран яруу, хүний сэтгэлийг хөдөлгөх гол чанар нь байхгүй болж зүгээр энгийн хүүрнэх өгүүлбэр мэт болжээ.

Зохиолын хэл найруулга сайн болоход олон зүйл нөлөөлөх боловч ойролцоо утгатай үг илүҮ Үүрэгтэй байдаг байна. Учир нь уран зохиолын найруулгын бусад төрлөөс ялгагдах гол онцлог нь өгүүлж буй зүйлээ зүгээр энгийн хэлэх бус уран дүрслэл, уран дүрээр өгүүлдгээрээ ялгардаг тул үүнд энгийн хүүрнэх өгүүлбэрийг уран яруу болгоход ойролцоо утгатай үг голлох нөлөөтэй байдаг. Тухайлбал, “Цахилж яваа гөрөөс" туужийн Дэжидийн тухай өгүүлсэн хэсэгт ажиглалт хийж үзье.

- Эх нь Дэжсидий долдугаар ангид орох намар сургуулиас нь гаргасанд тэр сургуульдаа сууна барина гэж зүтгэсэн ч үгүй эхийн аяс даган мал дээр гарч гэр бараа, идээ цагаа, нүҮдэл суудал гэсээр арван зургаа хүрэхэд нутгийн хариуул нас намба бүрдсэн хҮҮхэн хэмээн үзэж ярих хөөрөх, тоглох наадахдаа хорь хүрсэн бүсгүйтэй ярьдаг харьцдагийн нэг адил ярьдаг харьцдаг болж ирсэн нь нэгэн бодльин сайхан ч юм шиг, нэгэн бодльин ичмээр ч юм шиг санагдаж явсан тэр уед тэднийхээр бууж мордохдоо саатан, тугал ивэлгэх, саах нийлүүлэх зэрэгт санаагаараа тусалдаг, хүний нүд хариулан гарыг нь атгадаг хүн Дамба болжээ (х.12) гэсэн хэсэгт тэдгээр ойролцоо утгатай үгсийг хоршуулан хэрэглэснээр уг өгүүлбэрийн найруулга энгийн бөгөөд уран болсон төдийгүй, тухайн өгүүлж буй зүйлд зохиолын баатрын хандах хандлага давхар гарсан байна. Өөрөөр хэлбэл, дурдсан үгнүүд нь үгийн сангийн утгаа хадгалахын зэрэгцээ найруулгын нэмэлт утга гаргаж байгаа бөгөөд уншигчид түүнийг дор бүрнээ өөр өөрийн үзэл бодол, ертөнцийг үзэх үзлээр дүгнэн ойлгож болох юм. Тухайлбал, дээрх өгүүлбэрт Дэжид өөрийн өнгөрснийг дурсан санаж байгаа мэт боловч тэрээр анх насанд хүрсэн бүсгүй хүн болсноо мэдэрсэн тэр мэдрэмжээ одоо хүртэл мартаагүй, тэр бүхнийг санахад сэтгэлд нь сайхан байдаг гэсэн түүний сэтгэл хөдлөлийн өнгө аяс давхар ажиглагдаж байна. Энэ мэтчлэн зохиолд олон тооны ойролцоо утгатай үг тааралдах бөгөөд тэдгээрийг нуршин өгүүлэх нь илүүц бизээ.

Эсрэг үг. Зохиолын найруулгад ойролцоо утгатай үгээс гадна эсрэг утгатай үг багагүй Үүрэгтэй. Гэхдээ ойролцоо утгатай үг нь зохиолын уран яруу дүрслэлд нөлөөлдөг бол эсрэг үгийн утгын эрс тэс ялгааг ашиглан зохиолын үйл явдлын зөрчил, сайн муугийн ялгамжаа, тухайн юмны нарийн төвөгтэй, зөрчилтэй байдал зэргийг тодруулахад ашигладаг байна. Жишээ нь, зохиолын 66-р талд Дэжидийн дотоод сэтгэлд үүсч буй зөрчлийг дүрслэн ҮзҮүлэхдээ

“ХҮн гэдэг чинь ерөөс сайн сайхан, муу муухайгаа мартчихдаг /урьд өнгөрсөн бүхий л зүйлээ гэсэн утгатай С.M/ амьтан юм чинь" /үүгээрээ Дэжид Дамбын бүх явдлыг уучлаад, хуучнаараа амьдаръя гэж бодож байна/ хэмээн Дамбын явдалд дургүйцэж байсан хэдий ч үр хүүхдээ бодохоор, өөрийн ирээдүйг бодохоор бодол нь өөрчлөгдөн зөрчилдөж байгааг ҮзҮүлсэн энэ мэт жишээ зохиолд олон гарч байна.

...ТҮҮгээр ч барахгүй хэд хоног ирэхгүй болохоор нь гарч орох нь ихсэн хурга тугальнн хойноос мордох боловч ...

...Мөнөөх үнэн худал нь мэдэгдэхгүй яриаг магадгүй гэж бодох болгонд анхных нь тэр Үдэш дурсагдан, зүрхийг шимшрҮүлэхэд хоолой нь зангирч нүдний нь аяганд нулимс дүҮрэн, чавчихад уначихаар мэлтэгнэн ирнэ.

...Ямар хэргээр явааг нь бүY мэд, байдльг нь ажихад нэг л янзгүй мал бүрэн эсэхийг асууж лавласныхаа дараа дуртай дургүй “Дамба хайчаав?” хэмээн асуужээ.

...Харин чи ам муруйх болгондоо урьд хойчийн юм сөхөөд байв даa.

...Сайн муу ч гэсэн чамтай хэдэн жил ханилсан юм байна, юутай явуулахаа өнөөдөртөө мэдэх байлгүй гээд босч... 
...Ерөөс хол ойр алив юманд явахдаа гэрээдээ эргэж харж заншаагүйгээр ч үл барам $\cdots$

... Эмээл дээгүүрээ тохож орхичихоод ганзагаараа даруулаагүй боги нь морины явдалд урагш хойш бондогнон явааг ч үл анзаарах бөгөөд ...

... Улс амьтан боги тохоод хаа хүрэх нь вэ гэвэл юу хэлэх вэ, ойртож очоод хээр орхичихоод очих, Үдшээс өмнө айл саахалтын хүн олоод хэний юм наана цаана гэвэл бас эвгүй.

Этгээд үг. Нийтийн утга зохиолын хэлний хэм хэмжээнээс гажсан нийгмийн янз бүрийн бүлгийн хүмүүсийн хэл яриандаа хэрэглэж буй, хурдан хугацаанд хувьсан өөрчлөгдөж / хэрэглээнээс гардаг эсвэл шинээр бий болдог С.M/ нийгмийн сэтгэл зүйн илэрхийлэл болж байдаг үгсийг этгээд үг хэллэг гэдэг бөгөөд судлаачдын тэмдэглэснээр түүний хэрэглээнээс шалтгаалан нийтийн, мэргэжлийн, бүдүүлэг этгээд үг хэллэг [5:69-70] гэж хувааж болдог байна. Уран зохиол найруулгад этгээд үгийг зохиолын баатрын зан төрхийг тодруулахад ихэвчлэн ашигладаг. Жишээ нь, “Цахилж яваа гөрөөс тууж”-д Дамба өөрийн эхнэр хүүхдээ эргэх явах замдаа Агент Найдангийнхаар орох үед Найдангийн эхнэр Ханд гэгч тарган бор хүүхэн инээд алдан угтаж

-“Өчигдөрхөн шинэ бараа татсан даа. Юул авбал ав. Таануусын шилтэй иэнхэр хүртэл бий шүу гээд илүҮ гэрээ онгойлгон лангуу болгон тавьсан боов чихрийн хайриагны ард гарч зогсоод...” гэж өгүүлж буй хэсэгт “ШИЛТЭЙ ЦЭНХЭР” гэсэн үг гарч байна. Энэ үг 1990 оноос өмнө нийтийн ярианы хэлэнд идэвхтэй хэрэглэгдэж байгаад яваандаа хэрэглээ нь багассаар эдүгээ монгол хэлний үгийн санд нэгэнт хэрэглэгдэхээ больжээ. Учир нь “шилтэй цэнхэр” гэдэг нь архийг хэлж байгаа бөгөөд тухайн үед ганцхан улсын хүнсний үйлдвэрт цагаан архийг үйлдвэрлэдэг, тэр нь том дөрвөлжин, цэнхэр өнгийн шошготой худалдаанд гардаг байв. Харин 90 оноос хойш улсын үйлдвэр хувьд очин, олон хувийн үйлдвэрүүд өөр өөрсдийн шошго, лого бүхий архийг олноор үйлдвэрлэх болсноор энэ хэллэг хэрэглэгдэхээ больсон байна. Зохиогч агент Найдангийн эхнэрийн ярианд уг үгийг оруулснаар

- Харилцан ярьж буй хоёр хүний дунд өдөр тутмын ерийн нэг яриа үүсч буйг

- Энэ хоёр хүн нь насны хувьд ойролцоо, гэхдээ хэн хэнээ сайн мэддэг сайн нөхрийн холбоотой болохыг

- “Таануусын /“Та нарын” С.М/ шилтэй цэнхэр” гэснээр Хандын эр нөхөр, Дамба болон бусад найз нөхөр гэгдэх эрчүүд нийлж “шилтэй цэнхэр”-ээс үе үе хүртдэгийг

- Тухайн зохиолыг бичиж байх үед уг үг монгол хэлний үгийн санд идэвхтэй хэрэглэгдэж байсныг

тус тус илэрхийлж байгаа ба уг зохиолд ганцхан этгээд үг хэллэгийг ашигласнаараа ийм олон мэдээллийг уншигчдад өгөөд зогсохгүй тухайн хоёр хүний ярианы орчныг хөгжилтэй, эергүү болгон дүрсэлж чадсан байна.

Эцэст нь дүгнэн хэлэхэд СГЗ, зохиолч Д.Батбаярын “Цахилж яваа гөрөөс” тууж нь аяндаa бүтсэн юм шиг энгийн атлаа, хүний сэтгэлийн утсыг хөндсөн утга агуулга гүн гүнзгий, зохиолын хэл, найруулга утга төгөлдөр төдийгүй зохиолчийн ажигч гярхай зан, юмны учрыг гүн ухаарч ойлгодог, ургуулан бодох чадвар сайтайг илтгэсэн шилдэг бүтээл болсон байна. 


\section{Ном зүй}

1. Д.Батбаяр. “Цахилж яваа гөрөөс” Уб., 1984

2. Монгол хэлний дэлгэрэнгүй тайлбар толь Уб., 2008, I боть

3. Д.Отгонсүрэн "Уран зохиолын хэлний тухай” Уб., 1974

4. Орчин цагийн монгол хэлний үгсийн сангийн судлалын үндэс Уб., 1986

5. О.Самбуудорж., Л.Эрдэнэсувд “Монгол хэлний этгээд үг хэллэг” Уб., 2002

6. Ц.Сүхбаатар “Монгол хэлний найруулга зүй” Уб., 1998, х.260

7. .Төмөрцэрэн “Монгол хэлний үгийн сангийн судлал” Уб., 1974 